\title{
Study on occurrence and antibiogram pattern of Escherichia coli from raw milk samples in Anand, Gujarat, India
}

\author{
H. C. Thaker, M. N. Brahmbhatt, J B Nayak \\ Department of Veterinary Public Health \\ Veterinary College, Anand Agricultural University, Anand 388001, India. \\ Corresponding author: Harsh C. Thaker, e-mail: harshthaker2005@yahoo.co.in \\ Received: 24-03-2012, Accepted: 14-04-2012, Published Online: 11-06-2012 \\ doi: $10.5455 /$ vetworld.2012.556-559
}

\begin{abstract}
Aim: The study was carried out with aim to isolate Escherichia coli from raw milk samples and determine antibiogram pattern of $E$. coli isolates.

Materials and Methods: During 6 months duration of study a total of 100 raw milk samples were collected from different places in and around Anand city such as individual household, cattle farms, milk collection centres of Co-operative milk dairies and milk vendors. All raw milk samples were enriched in peptone water and inoculated on selective media and various biochemical tests were performed for confirmation of isolates. Antibiogram pattern of E.coli to antimicrobial agents was evaluated by disk diffusion method. E. coli isolates were sent to National Salmonella and Escherichia Centre, Central Research Institute, Kasauli, Himachal Pradesh for serotyping.

Results: The result of present study revealed that out of 100 samples, 38 samples were found contaminated with E.coli. Antibiogram pattern revealed high resistance against ampicillin (100\%), whereas moderate resistance was observed for streptomycin $(57.89 \%)$, oxytetracycline $(47.37 \%)$ and amoxy-clav $(42.11 \%)$. Also lesser percentage of resistance was observed for co-trimoxazole (13.16\%) and chloramphenicol (5.26\%). Serotypes detected were O24 (7 isolates), followed by O36 (1 isolate), O89 (1 isolate), O91 (1 isolate) and O153(1 isolate).

Conclusions: Results suggested a possibility of potential public health threat of E.coli originating from raw milk sources. Key words: Antibiogram pattern, E.coli, Enteropathogenic, Raw milk, Serotypes.
\end{abstract}

To cite thisarticle:

Thaker HC, Brahmbhatt MN, Nayak JB (2012) Study on occurrence and antibiogram pattern of Escherichia coli from raw milk samples in Anand, Gujarat, India, Vet World, 5(9): 556-559, doi: 10.5455/vetworld.2012.556-559

\section{Introduction}

Food safety and quality is a topic of public concern throughout the world. Well publicized and widespread food borne disease outbreaks have created an awareness of potential threats to human health from food products. Markets and consumers for raw milk and their products have existed in many parts of the world. Raw or processed milk is a well-known good medium that supports the growth of several microbes with resultant spoilage of the product or infections/ intoxications in consumers [1,2].

Generally, bacteria in the milk can occur through colonization of the teat canal or an infected udder (clinical and subclinical mastitis) or gets contaminated at various stages be it from the animal, milker (manual as well as automated), extraneous dirt or unclean water [3-7]. Many microorganisms can get access to milk and milk products, among these are $E$. coli. Coliforms and $E$. coli are often used as marker organisms [8, 9, $10]$. Recovery and counting of $E$. coli is used as reliable indicator of fecal contamination and indicates a possible presence of enteropathogenic and/or toxigenic microorganisms which constitute a public health hazard [11]. E. coli is one of the main inhabitants of the intestinal tract of most mammalian species, including humans and birds. Most E. coli are harmless, but some are known to be pathogenic bacteria, causing severe intestinal and extra intestinal diseases in man [12]. The milk sold in raw forms and because of possibilities of contamination with E. coli posses a great hazard to public health [13].

In addition to the presence of $E$. coli denoting fecal contamination, the presence of virulence related genes in E. coli strains refer to the pathogenicity of the isolates. Previous studies documented the presence of some $E$. coli isolates from raw milk and products for virulence markers [14-17].

Thus, the objective of this study was to investigate the occurrence of the opportunistic pathogen E. coli in raw milk, determine antibiogram pattern and serotyping of E. coli isolates.

\section{Materials and Methods}

Sample collection: From February 2011 to July 
Study on occurrence and antibiogram pattern of Escherichia coli from raw milk samples in Anand, Gujarat

\begin{tabular}{lll}
$\begin{array}{l}\text { Table-1. Morphological and culture characteristics of } \\
\text { bacteria }\end{array}$ & \\
\hline Isolated bacteria & Gram staining & $\begin{array}{l}\text { Culture characteristics on } \\
\text { selective media }\end{array}$ \\
\hline Escherichia coli & Gram negative & $\begin{array}{l}\text { Mac Conkey Agar: Pink } \\
\text { coloured colonies. } \\
\text { Eosin Methylene Blue agar: } \\
\text { Metallic sheen. }\end{array}$ \\
\hline
\end{tabular}

Table-3. Antibiogram pattern of 38 E.coli isolates from raw milk

\begin{tabular}{lcc}
\hline Antimicrobials & No. of resistance & \% resistance \\
\hline Ampicillin & 38 & 100.00 \\
Streptomycin & 22 & 57.89 \\
Oxytetracycline & 18 & 47.37 \\
Amoxy-clav & 16 & 42.11 \\
Co-trimoxazole & 5 & 13.16 \\
Chloramphenicol & 2 & 5.26 \\
\hline
\end{tabular}

2011, a total of 100 raw milk samples were randomly collected in sterilized screw capped bottles from different localities in and around Anand city such as individual household, cattle farms, milk collection centres of Co-operative milk dairies and milk vendors. The milk samples were transported in a cool box to the laboratory of the Post Graduate Department of Veterinary Public Health, College of Veterinary Science \& Animal Husbandry, AAU, Anand and tested within 24 hrs for the isolation and identification of E.coli.

I solation and identification of Escherichia coli: Isolation of E.coli was attempted according to Singh and Prakash [18] with slight modification. A part of each sample $(10 \mathrm{ml})$ was enriched in peptone water (HiMedia Pvt. Ltd.) $(90 \mathrm{ml})$ and was incubated at 37 ${ }^{\circ} \mathrm{C}$ for 24 hours. Enriched samples were inoculated on Mac Conkey Agar (MCA) (HiMedia Pvt. Ltd.) a dual purpose (selective and differential) medium, by four flame technique and plates were incubated at $37{ }^{\circ} \mathrm{C}$ for 24 hours. Pink coloured colonies appeared were considered as presumptive of E.coli.

A single isolated colony was picked and streaked on Eosin Methylene Blue Agar (EMB) medium (HiMedia Pvt. Ltd.) and incubated at $37{ }^{\circ} \mathrm{C}$ for 24 hours. E. coli produces metallic sheen on EMB agar. Such colonies were taken into nutrient broth for further biochemical examination.

Biochemical examination: Biochemical tests were performed to confirm E. coli using Gram staining, Catalase test, Indole, Methyl red, Voges- Proskauer test, Nitrate reduction, Citrate utilization and Urease production.

Antibiogram pattern of the isolated E.coli to some antimicrobial agents: The susceptibility of
Table-2. Biochemical characterisation of E. coli

\begin{tabular}{lc}
\hline Biochemical test & Reaction \\
\hline Catalase & + \\
Indole & + \\
Methyl red & + \\
Voges-Proskauer & - \\
Citrate utilization & - \\
Nitrate reduction & + \\
Urease & - \\
\hline
\end{tabular}

Table-4. Serotyping results obtained from Central Research Institute, Kasauli

\begin{tabular}{llc}
\hline Sr. no. & Serotypes & No. of isolates \\
\hline 1 & O24 & 7 \\
2 & O36 & 1 \\
3 & O89 & 1 \\
4 & O91 & 1 \\
5 & O153 & 1 \\
6 & Untypable & 3 \\
7 & Dead during transit & 24 \\
\hline
\end{tabular}

isolates to different antimicrobial agents was done by disk diffusion method using commercial disks [19] procured from HiMedia Pvt. Ltd. and almost all antimicrobial agents were having expiry date after 5-6 months of completion of research.

The antimicrobial agents tested were the following: ampicillin $(10 \mu \mathrm{g})$, amoxy-clav $(30 \mu \mathrm{g})$, chloramphenicol $(20 \mu \mathrm{g})$, co-trimoxazole $(30 \mu \mathrm{g})$, oxytetracycline $(30 \mu \mathrm{g})$, streptomycin $(10 \mu \mathrm{g})$.

Serotyping of E. coli isolates: Isolates were sent to National Salmonella and Escherichia Centre, Central Research Institute, Kasauli, Himachal Pradesh.

\section{Results}

In the present study, it was revealed that 38 samples $(38.00 \%)$ out of 100 raw milk samples were found positive for Escherichia coli according to morphological and cultural characteristics (Table 1) and biochemical tests (Table 2).

The antibiogram pattern revealed that 38 E.coli isolates showed high resistance against ampicillin $(100 \%)$, whereas moderate resistance was observed for streptomycin $(57.89 \%)$, oxytetracycline $(47.37 \%$ ) and amoxy-clav $(42.11 \%)$. Also lesser percentage of resistance was observed for co-trimoxazole $(13.16 \%)$ and chloramphenicol $(5.26 \%)$ (Table 3$)$.

The serotyping report received from National Salmonella and Escherichia Centre, Central Research Institute, Kasauli revealed that serotypes detected were $\mathrm{O} 24$ (7 isolates), followed by O36 (1 isolate), O89 (1 isolate), O91 (1 isolate) and O153(1 isolate) (Table 4).

\section{Discussion}

E.coli is not only regarded as an indicator of 
fecal contamination but more likely as an indicator of poor hygiene and sanitary practices during milking and further handling. Higher prevalence of E.coli was reported by Ali and Abdelgadir [11] who found $63 \%$ prevalence and Lingathurai and Vellathurai [20] who found $70 \%$ prevalence. The incidence of the species of $E$. coli itself in milk and milk products, as a possible cause of food born disease, is not significant if $E$. coli is normally an ubiquitous organism [21], yet the pathogenic strains if present could be harmful to consumers.

Coliform bacteria can be carried into milk duct of the cow during milking by suction of the milking machine and then flushed out during subsequent milking without causing clinical symptoms of infection. Previous studies provided evidence that Escherichia coli are frequently occurring organism in milk. The methods of production, transportation, handling and sale of milk are entirely unhygienic [11]. High incidence of $E$. coli was found in different types of milk by many researchers [22-26]. In India, the raw milk and products were heavily contaminated by E.coli [9]. In South Africa, Lues et al. [27] detected a higher percentage of E.coli in raw milk. In Malaysia, Chye et al. [28] indicated that $90 \%$ of the examined raw milk were contaminated by coliform bacteria and $65 \%$ were E.coli positive. In Saudi Arabia, Salji et al. [29] recorded coliforms as the main contaminants of raw milk. Moreover in Saudi Arabia, Al-Kanhal et al. [30] reported that coliforms count exceeded the American standards in most of the dairy plant studied. Antibiotic resistance development among the bacteria poses a problem of concern. Effectiveness of current treatments and ability to control infectious diseases in both animals and humans may become hazardous.

Out of 5 different serotypes found in this study, $\mathrm{O} 24, \mathrm{O} 36$ and $\mathrm{O} 89$ are not associated with clinical conditions, whereas serotypes O91 and O153 are associated with bloody diarrhea (Haemolytic uremic syndrome) in humans.

Serotypes like O157, O26, O8, O55, O86, O126 and $\mathrm{O} 128$ have been found to be associated with infantile diarrhoea among neonates and adult human patients suffering from gastroenteritis as reported by Beutin et al. [31] and Nishikawa et al. [32]. Thus, these serotypes may be of zoonotic importance. In present study, none of the above serotypes were found but still the virulence of $E$. coli should not be considered less.

\section{Conclusion}

Results clearly indicated that microbial quality and safety of raw milk produced by local farmers and distributors was unsafe. The presence of fecal indicator organism not only indicates the poor hygiene but also itself may be pathogenic. The pathogenic bacteria such as E.coli may pass to the milk; this suggests that raw milk should be considered a vehicle for the transmission of potentially pathogenic bacteria. For this, hygienic milk production techniques should be followed such as regular sterilization of dairy equipment, washing of utensils, milker's hands, udder, , etc. As well as pasteurization or boiling of milk prior to consumption is required. Frequent use of antibiotics should be stopped as antibiotic resistant strains are continuously increasing. This study highlights the need for continuous surveillance of antibiotic sensitivity pattern of E.coli with a view to selecting appropriate therapy.

\section{Author's contribution}

HC Thaker, MN Brahmbhatt and J B Nayak implemented the study design and analyze samples. HC Thaker analyzed the data. HC Thaker, MN Brahmbhatt and JB Nayak drafted and revised the manuscript. All the authors read and approved final manuscript

\section{Acknowledgements}

Authors are grateful to the Department of Veterinary Public Health, Anand Agricultural University, Anand for giving financial support to the present investigation and also thankful to the National Salmonella and Escherichia Centre, Central Research Institute, Kasauli, Himachal Pradesh for serotyping of E. coli isolates.

\section{Competing interest}

Authors declares that they have no competing interest.

\section{References}

1. Murinda, S.E., Nguyen, L.T., Man, H.M. and Almedia, R.A. (2004). Detection of sorbitol negative and sorbitol-positive shiga toxin-producing E. coli, Listeria monocytogenes, Campylobacter jejuni and Salmonella species in dairy farm environments. Food-borne Pathogens and Dis., 1:97-104.

2. Oliver, S.P., Jayarao, B.M. and Almedia, R.A. (2005). Food borne pathogens in milk and the dairy environment food safety and public health implications. Foodborne Pathogens and Dis., 2: 1115-1129.

3. Banwart, G.J. (1989). Microorganisms associated with food (2nd ed.). Basic food microbiology. New York: Van Nostrand Reinhold.

4. Murphy, S.C. (1996). Sources and Causes of High Bacteria Count in Raw Milk: an Abbreviated Review. Cornell University, Ithaca, N.Y.: 1-4.

5. Gruetzmacher, T.J. and Bradley, R.L. Jr. (1999). 
Identification and control of processing variables that affect the quality and safety of fluid milk. J. Food Prot., 62: 625-631.

6. Godefay, B. and Molla, B. (2000). Bacteriological quality of raw milk from four dairy farms and milk collection center in and around Addis Ababa. Berl. Münch. Tierärztl. Wschr., 113:1-3.

7. Hayes, M.C., Ralyea, R.D., Murphy, S.C., Carey, N.R., Scarlett, J.M. and Boor, K. J. (2001). Identification and characterization of elevated microbial counts in bulk tank raw milk. J. Dairy Sci. 84: 292-298.

8. Diliello, L.R. (1982). Methods in Food and Dairy Microbiology. AVI publishing Co. Inc. Westport Connt. USA: 39

9. Soomro, A.H., Arain, M.A., Khaskheli, M. and Bhutto, B. (2002). Isolation of Escherichia coli from raw milk and milk products in relation to public health sold under market condition at Tandojam. Pak. J. Nutr., 1(3): 151-152.

10. Benkerroum, N., Bouhal, Y., EI Attar, A. and Marhaben, A. (2004). Occurrence of Shiga toxinproducing E. coli $0157: \mathrm{H} 7$ in selected diary and meat products marketed in the city of Rabat, Morocco. $J$. Food. Prot., 67(6): 1234-1237.

11. Ali, A.A. and Abdelgadir, W.S. (2011). Incidence of Escherichia coli in Raw Cow's Milk in Khartoum State. British J. Dairy Sci., 2(1): 23-26.

12. Kaper, J.B., Nataro, J.P. and Mobley, H.L.T. (2004). Pathogenic Escherichia coli. Nat. Rev. Microbiol., 2: 123-140.

13. Rea, M. and Fleming, M.G. (1994). Escherichia coli (ETEC). In: The Significance of Pathogenic Microorganisms in Raw Milk, International Dairy Federation. IDF,Brussels, Beljium.: 91-100.

14. Klie, H., Timm, M., Richter, H., Gallien, P., Perlberg, K. W. and Steinruck, H. (1997). Detection and occurrence of verotoxin-forming and/or Shigatoxin producing Escherichia coli (VTEC and/or STEC) in milk. Berliner und Munchener Tierarztliche Wochenschrift, 110:337-341.

15. Jayarao, B.M. \& Henning, D.R. (2001). Prevalence of foodborne pathogens in bulk tank milk. J. of Dairy Sci., 84: 2157-2162.

16. Holko, I., Bisova, T., Holkova, Z. and Kmet, V. (2006). Virulence markers of Escherichia coli strains isolated from traditional cheeses made from unpasteurised sheep milk in Slovakia. Food Control, 17: 393-396.

17. Paneto, B.R., Schocken-Iturrino, R.P., Macedo, C., Santo, E. and Marin, J. M. (2007). Occurrence of toxigenic Escherichia coli in raw milk cheese in Brazil. Arquivo Brasileiro de Medicina Veterinariae Zootecnia, 59: 508-512.

18. Singh, P. and Prakash, A. (2008). Isolation of Escherichia coli, Staphylococcus aureus and Listeria monocytogenes from milk products sold under market conditions at Agra region, Acta agriculturae Slovenica., 92(1): 83-88.
19. Bauer, A.W., Kirby, W.M.M., Sherris, J.C. and Turck, M. (1966). Antibiotic susceptibility testing by a standardized single disk method. Amer. J. Clin. Pathol., 45: 493-496.

20. Lingathurai, S. and Vellathurai, P. (2010). Bacteriological Quality and Safety of Raw Cow Milk in Madurai, South India. http://www.webmedcentral. com/article view/1029.

21. Hahn, G.(1996). Pathogenic bacteria in raw milk situation and significance. In: Bacteriological quality of raw milk. Brussels (Belgium), Int. Dairy Federation.: 67-83.

22. Martin, M.L., Shipman, L.D., Potter, M.E., Wachsmuth, L.K., Wells, J.G., Hedberg, K., Tauxe, R.V., Davis, J.P. and Tilleli, J. (1986). Isolation of Escherichia coli $\mathrm{O} 157: \mathrm{H} 7$ from dairy cattle associated with two cases of hemolytic uraemic syndrome. Lancet, 8514: 1043.

23. Hanjra, S.H. and Khan, B.B. (1989). Market Quality of Milk in Pakistan. Dairy Technology in Pakistan. PARC, Islamabad: 58

24. Ahmed, A.M. and Sallam, S.S. (1991). Prevalence of E. coli serotypes in raw milk and some dairy products. Assiut. Vet. Med. J., 25: 93-97.

25. Sharma, D.K. and Joshi, D.V.(1992). Bacteriological quality of milk and milk products with special reference to Salmonella and its public health significance. J. Food Sci. Tech. Mysore, 29: 105-107.

26. Adesiyun, A.A. (1994). Bacteriological quality and associated public health risk of pre-processed bovine milk in Trinidad. Int. J. Food Microbiol., 21: 253-261.

27. Lues, J.F.R., Venter, P. and van der Westhuizen, H. (2003). Enumeration of potential microbiological hazards in milk from a marginal urban settlement in central South Africa. Food Microbiol., 20:321-326.

28. Chye, F.Y., Abdullahb, A. and Ayobb, M.K. (2004). Bacteriological quality and safety of raw milk in Malaysia. Food Microbiol., 21:535-541.

29. Salji, J.P., Sawaya, W.N. and Ayaz, M. (1984). Fluid milk industry in the central province of Saudi Arabia J. Dairy Sci., 67: 1054-1060.

30. Al-Kanhal, H. A., Abo-Tarboosh, H. M., Hamad, A M. and Al-Shrawy, M. I. (1996). The quality of raw milk produced in Saudi Arabia. J. King Saud Uni., Agricult. Sci., 8:211-226.

31. Beutin, L., Montenegro, M.A., Orskov, I., Orskov, F., Prada, J., Zimmermann, S. and Stephan, R. (1989). Close association of verotoxin (shiga-like toxin) production with enterohemolysin production in strains of E. coli. J. Clin. Microbiol. 27: 2559-2564.

32. Nishikawa, Y., Zhou, Z., Hase, A., Ogasawara, J., Kitase, T., Abe, N., Nakamura, H., Wada, T., Ishii, E., Haruki, K. and the Surveillance Team (2002). Diarrheagenic Escherichia coli isolated from stools of sporadic cases of diarrheal illness in Osaka city, Japan between 1997 and 2000: Prevalence of Enteroaggregative E. coli heat stable enterotoxin 1 genepossessing E. coli. Jpn. J. Infect. Dis. 55: 182-190. 